\title{
FIRST REPORT OF SUGARCANE MOSAIC VIRUS IN ZEA MAYS L. IN UKRAINE
}

\author{
H. Snihur ${ }^{1,2}$, A. Kharina ${ }^{1}$, M. Kaliuzhna ${ }^{3}$, \\ V. Chumak', I. Budzanivska ${ }^{1}$ \\ 'Taras Shevchenko National University, ESC "Institute of Biology and Medicine", \\ Virology Department, \\ 64/13 Volodymyrska Str., Kyiv, 01601, Ukraine \\ ${ }^{2}$ Zabolotny Institute of Microbiology and Virology, NAS of Ukraine, \\ 154 Acad. Zabolotny Str., Kyiv, 03143, Ukraine \\ ${ }^{3}$ I.I. Schmalhausen Institute of Zoology, NAS of Ukraine, Department \\ of Taxonomy of Entomophagous Insects and Ecological Principles of Biocontrol, \\ 15 B. Khmelnytskogo Str., Kyiv, 01030, Ukraine \\ ${ }^{4}$ State Institution of Higher Education "Uzhgorod National University», \\ Department of Entomology and Biodiversity Conservation, \\ 3 Narodna Square, Uzhhorod, 88000, Ukraine \\ e-mail:galya_snigur@yahoo.com
}

Maize viral diseases especially maize dwarf mosaic disease (MDMD), which is caused by potyviruses, lead to significant crop losses worldwide. Aim. The aim of this work was to identify the causal agent of mosaic symptoms, observed on maize plants during 2018-2020 in Kyiv region. Methods. Enzyme-linked immunosorbent assay in the DAS-ELISA modification using commercial Loewe Biochemica test systems for Maize dwarf mosaic virus (MDMV), Sugarcane mosaic virus (SCMV), Wheat streak mosaic virus (WSMV) were applied to identify the causal agent of maize disease in collected samples. Transmission electron microscopy was used in order to direct viral particle visualisation. Aphids, which are natural vectors of plant viruses, were found on diseased plants. Results. Plants with typical mosaic symptoms were observed in corn crops of the Kyiv region in early June 2018. The pathogen was transmitted by mechanical inoculation to maize and sweet maize plants with the manifestation of mosaic symptoms. Electron microscopy of the sap from diseased plants revealed the presence of flexible filamentous virions $750 \mathrm{~nm}$ long and $13 \mathrm{~nm}$ in diameter, typical for the genus Potyvirus. In August, mosaic symptoms and aphids Rhopalosiphum padi were found on previously healthy plants in the same maize crop. In 2020, in the same sown area, maize plants were free of viral infection during inspection in June, but a re-inspection in September revealed mosaic symptoms on maize crop and the presence of aphids in the leaf axils. The presence of SCMV in maize samples collected in June and August/September 2018 and 2020, as well as in inoculated maize and sweet maize plants, was confirmed by ELISA using a commercial test system. The obtained data allow suggesting that Rhopalosiphum padi is a natural vector of SCMV in agrocenoses of Ukraine. It should be noted that co-infection with MDMV and WSMV in the affected plants was not detected. Conclusions. This study presents the first report of SCMV in maize in Ukraine.

Keywords: Sugarcane mosaic virus, identification, Double antibody sandwich-ELISA, maize, Rhopalosiphum padi.

Maize (Zea mays L.) is one of the most cultivated crops in the world. Ukraine is among the leaders of maize production and ranks sixth in the world after the United States, China, Brazil, the EU, and Argentina. A further increase in maize acreage in Ukraine is expected. Maize dwarf mosaic disease (MDMD) is one of the most common and economically important viral diseases of maize in many countries [1]. For a long time two potyviruses, Maize dwarf mosaic virus (MDMV) and Sugarcane mosaic virus (SCMV), were considered as the causative agents of this disease, due to similar virion morphology, range of host plants, transmission modes, physical and chemical properties [2]. These pathogens share a virion morphology, and composed of filamentous flexible virus particles $13 \mathrm{~nm}$ in a diametr, $770 \mathrm{~nm}$ in length for MDMV and $750 \mathrm{~nm}$ for SCMV. In 1992 
Shukla et al. showed that the cereal potyvirus group consists of four different viruses, including MDMV, SCMV, Sorghum mosaic virus (SrMV), and Johnsongrass mosaic virus (JGMV) [3]. A procedure has been developed to assess the presence of potyviruses in samples of infected cereals, followed by identification of the virus species or mix of species (in case of co-infection) of the genus Potyvirus [4]. MDMV and SCMV have been identified in maize plants on all continents [5-16], JGMV was found in Johnsongrass (Sorghum halepense), elephant grass (Pennisetum purpureum) and maize in Australia, USA, Brazil and Africa [17, 18], and SrMV was identified in maize only in the USA and on sugar cane in China and India $[1,3,19$, 20]. MDMV is the most common pathogen among all the viruses that infect maize worldwide [21]. In general, maize yield losses caused by MDMV can reach up to $70 \%$ [22], mainly due to a decrease in photosynthesis rate and an increase in the respiration rate $[23,24]$. SCMV is known to cause yield losses up to $50 \%$ in susceptible varieties of both maize and sugar cane [25]. MDMV and SCMV are important causative agents of viral diseases in European maize production, leading to severe yield losses of grain and animal forage in susceptible maize varieties $[20,26,27]$. In the Czech Republic SCMV prevails over MDMV in maize: during 3-year observations it occurred in $98.7 \%$ samples, while MDMV was identified only in $1.3 \%$ samples [28]. In Poland SCMV is also considered to be more economically important in maize production compared to MDMV, however these viruses are also found in mixed infections in different regions of the country [29].

MDMV and SCMV are transmitted by aphids in an non-persistent mode. There are more than 20 different species of aphids capable of transmitting MDMV, in particular, Rhopalosiphum maidis, Myzus persicae, Rhopalosiphum padi and Brevicoryne brassicae; SCMV vectors are Hysteroneura setariae, Rhopalosiphum maidis, Rhopalosiphum padi, Schizaphis graminum, Aphis gossypii, Myzus persicae [30, 31]. The efficiency of MDMV transmission by aphids is directly and/or indirectly affected by various factors such as temperature and humidity, virus strain, vector species. The characteristics of host plant (species, variety, age) and environmental factors significantly affect the in vivo virus concentration in plants $[30,32]$. Transmission of the virus by aphids depends on virion retention in aphid stylets; MDMV retention was much longer with increasing time of virus acquisition [33, 34].
In addition to aphid transmission, MDMV and SCMV can also be transmitted by mechanical inoculation and seeds. The percentage of MDMV seed transmission in maize ranges from $0.006 \%$ [35] to $0.5 \%$ [36], and SCMV seed transmission in maize and sweet maize is about $0.4 \%$ [37].

MDMV and SCMV are systemic viruses that infect most parts of the plant; the main manifestations of infection are the development of mosaic leaves, light or yellow-green chlorotic areas, and there may also be redness and necrosis on the leaves and stems. Severely infected plants demonstrate plant growth retardation, increased tillering and a poor seed yield. Infected plants are more susceptible to root rot pathogens [23, 38]. SCMV in co-infection with Maize chlorotic mottle virus (MSMV) causes fatal maize necrosis in some parts of East Africa [39].

In 1970-1971 Naumenko [40] identified the causative agent of maize mosaic in Ukraine. Comparing the range of host plants, ways of transmission, properties in the sap, virion morphology of the pathogen detected in Ukraine, the researcher concluded that this virus is identical to the virus described in Europe (maize mosaic virus) and in the United States (MDMV) [40]; the presence of mosaic in maize fields in Kyiv, Dnipropetrovsk, and Kherson regions was shown [41]. The pathogen was transmitted from mosaic plants to healthy ones by mechanical inoculation of the sap, as well as by aphids Myzus persicae and Rhopalosiphum maidis without an incubation period in the insects [40]. After these reports, there was no information about maize viruses and viral diseases in Ukraine.

\section{Material and Methods}

\section{Maize Leaf Samples and Plant Inoculation}

We conducted a monitoring of industrial maize fields for the presence of viral diseases in the Kyiv region at the beginning of June 2018 and 2020. Plants with characteristic symptoms of mosaic were selected for further examination. In August/ September inspections of the fields were repeated; special attention was paid to the examination of the fields, where infected plants were found in June.

For infection biotesting we took leaves from symptomatic plants of maize "Mosquito" and sweet maize "Brusnytsia", homogenized them with a mortar in $0.05 \mathrm{M}$ potassium phosphate buffer $\mathrm{pH}$ 7.0 (ratio 1:10) and inoculated directly on young plant leaves (5 weeks old) with carborundum as an abrasive [42]. Three weeks after infection, the results were recorded. 
Transmission electron microscopy (TEM)

Extracts obtained from various symptomatic maize plants were placed on grids and negatively contrasted with $2 \%$ uranyl acetate. Samples were observed under JEOL (JEM-1400) transmission electron microscopy in the Centre of collective usage of the NAS of Ukraine at D.K. Zabolotny Institute of Microbiology and Virology of the NASU [43].

Double antibody sandwich-ELISA (DAS-ELISA)

Enzyme-linked immunosorbent assay in the DAS-ELISA modification was used to identify the pathogen. Collected samples of maize were tested for MDMV, SCMV, and Wheat streak mosaic virus (WSMV) using commercial test systems Loewe Biochemica (Germany). The analysis was performed according to standard methods following the manufacturer's instructions. Standard (positive and negative) commercial controls were used in the analysis. The reaction was considered positive if the optical density at a wavelength of $405 \mathrm{~nm}$ of the test sample exceeded the negative controls at least three times and was higher than 0.2 [44].

Aphid species identification

Aphids were identified using morphological identification keys [46, 47-48].

Results. During inspection of industrial maize fields in Kyiv region in early June 2018, in one field we found plants at the stage of four-five leaves with virus-like mosaic symptoms (Fig. 1). It should be noted that the plants with mosaic symptoms were solitary and distributed evenly throughout the sown area, which may indicate the seed origin of the infection.

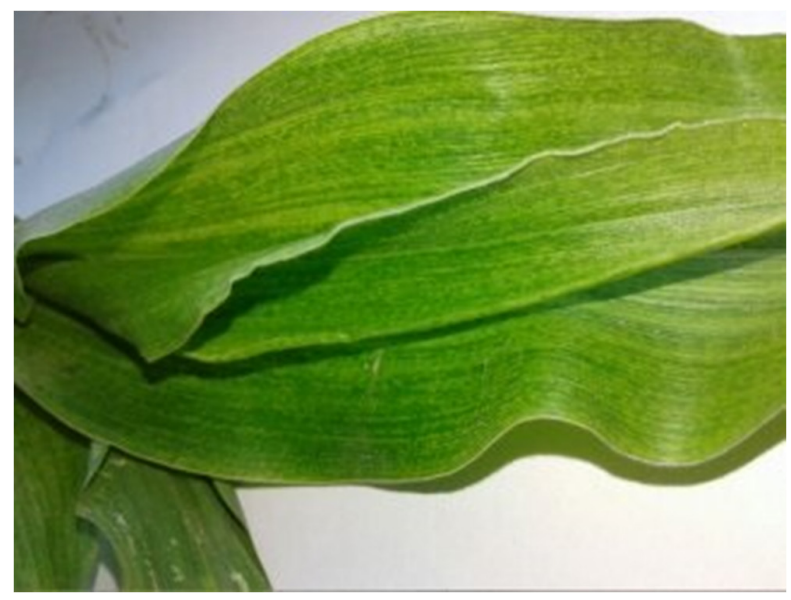

F i g. 1. Mosaic symptoms on Zea mays plants sampled in the fields of Kyiv region in June 2018

Biotesting of the pathogen on plants of maize "Mosquito" and sweet maize "Brusnytsia" showed symptoms at the base of the youngest leaves in two weeks post inoculation, and in three weeks after inoculation symptoms of clear mosaic were recorded on the maize leaves (Fig. 2).

Electron microscopic examination of the sap from symptomatic maize plants revealed the presence of flexible filamentous viral particles about $750 \mathrm{~nm}$ long and $13 \mathrm{~nm}$ in diameter (Fig. 3).
A

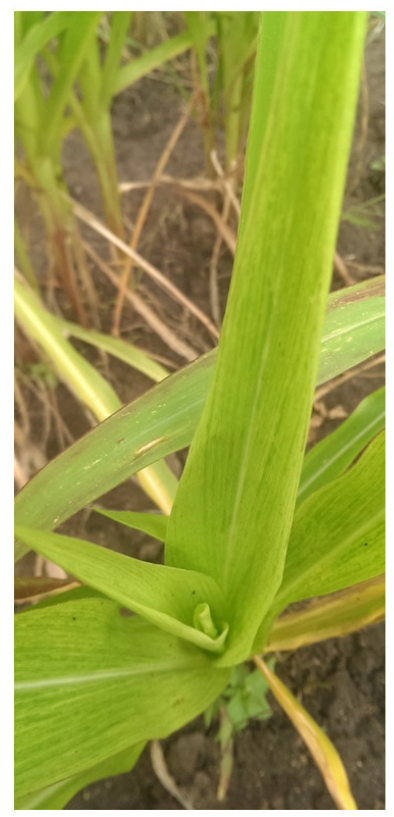

B

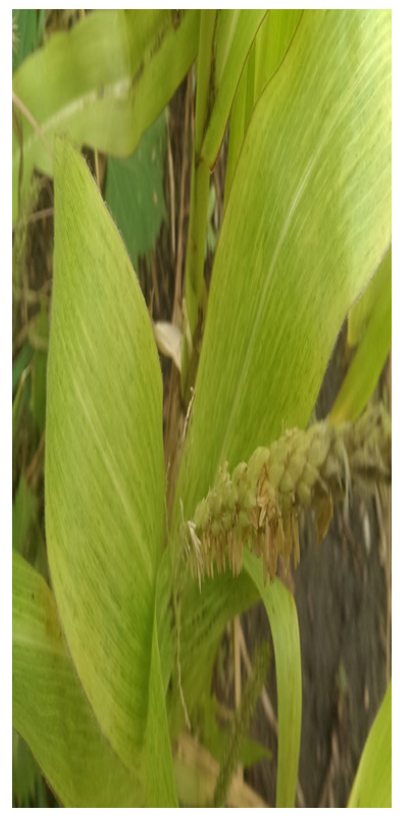

C

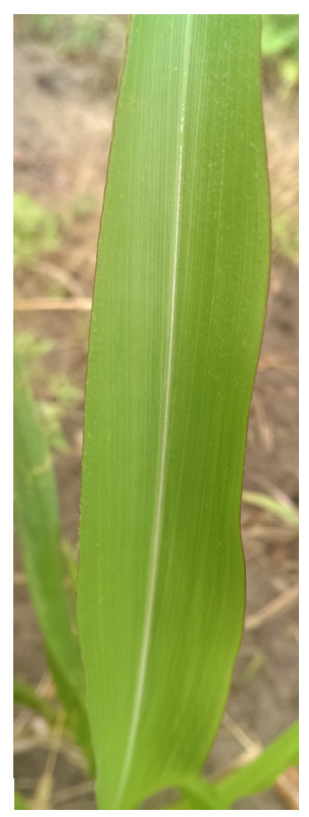

F i g. 2. Symptoms on inoculated maize plants: a) "Mosquito" variety; b) "Brusnytsia" variety; c) "Mosquito" variety non-inoculated control 


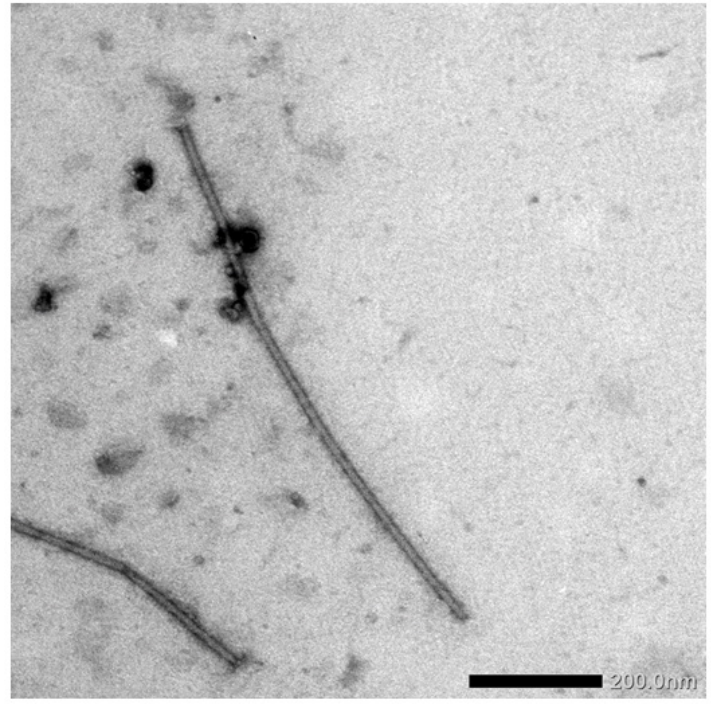

F i g. 3. Electron microscopic image of viral particles detected in the sap from maize plants showing mosaic symptoms (scale bar $200 \mathrm{~nm}$ )
During re-examination of maize field in August 2018, we found mosaic symptoms along with Rhopalosiphum padi aphids on previously healthy plants (Fig. 4).

In 2020, maize was sown again on the same field, and a visual inspection of the plants in June revealed no symptoms typical of a viral infection in that crop. Upon re-examination of the field in September, we found plants with symptoms of mosaic and growth retardation. Aphids Rhopalosiphum padi were observed in the leaf axils (Fig. 5).

Serological testing with DAS-ELISA using a commercial test system showed the presence of SCMV in maize samples collected in both June and August/September 2018 and 2020, as well as in inoculated maize and sweet maize plants (Fig. 6). It should be noted that co-infection with MDMV and WSMV in the infected plants was not detected.
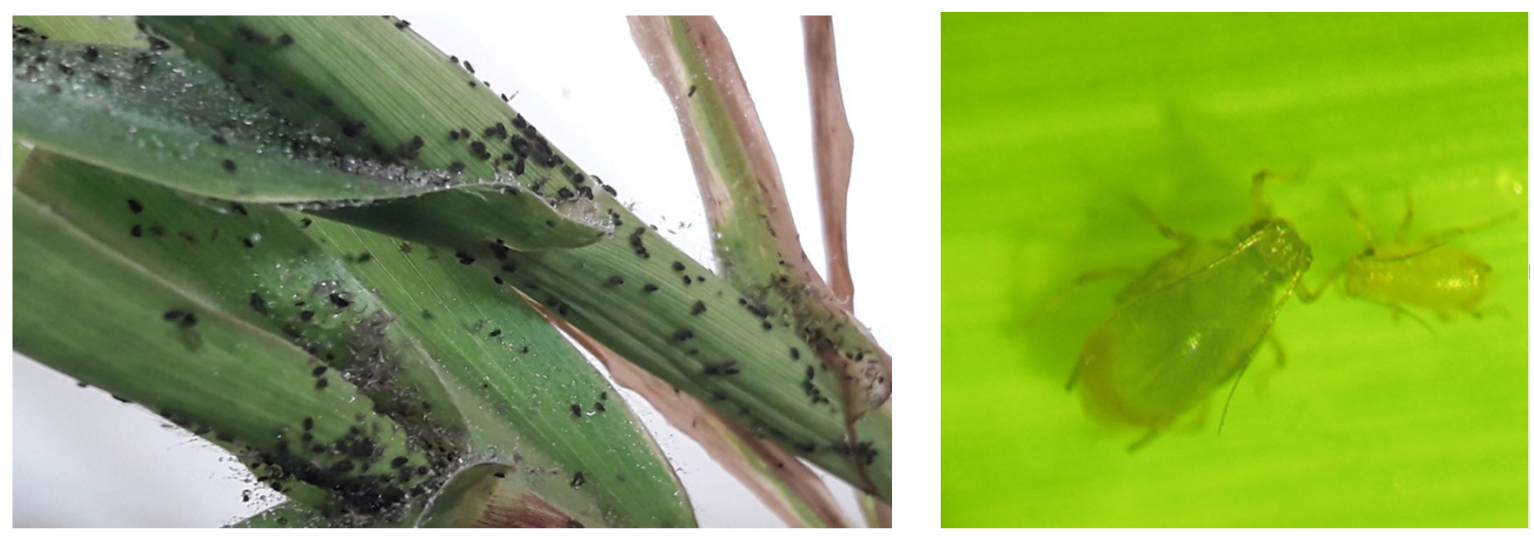

F i g. 4. Symptoms of mosaic and aphid Rhopalosiphum padi on maize plants in August 2018 (a); aphids under magnification (b)

Discussion. The results obtained by visual inspection of the industrial maize field, and by biotesting with mechanical inoculation method with the appearance of the same symptoms of mosaic on maize plants, as well as electron microscopic examination and analysis of facts indicating the possibility of transmission of the pathogen by seeds and aphids, allowed to conclude that plants were infected with one of potyviruses [4, 24]. The analysis of the publications focused our attention on three potyviruses that can infect maize and are common on cereals in Ukraine and/or neighboring countries: MDMV, SCMV and WSMV, which is a representative of the genus Tritimovirus of the family Potyviridae. In addition, there was a need for an excluding of co-infection with these maize plant viruses, as such facts have been repeatedly described in the literature [28-29, 48-49].
Serological testing showed that the maize was infected by the SCMV and confirmed the absence of a mixed infection with MDMV and WSMV. It should be noted that this is the first report of SCMV in Ukraine. Similar data on the distribution of SCMV in maize in other European countries have been published repeatedly, particularly in the Czech Republic [28], Poland [29], Germany [48], Spain [26] and France [27].

The fact that in 2018 mosaic symptoms were observed on sporadic and evenly distributed maize plants at the stage of only four-five leaves give us the possibility to assume the seed origin of the infection in this field. It should be noted that in 2020, during a detailed examination of maize plants on the same sown area, we did not find the characteristic symptoms of mosaic. Detection of mosaic symptoms together with aphids on 

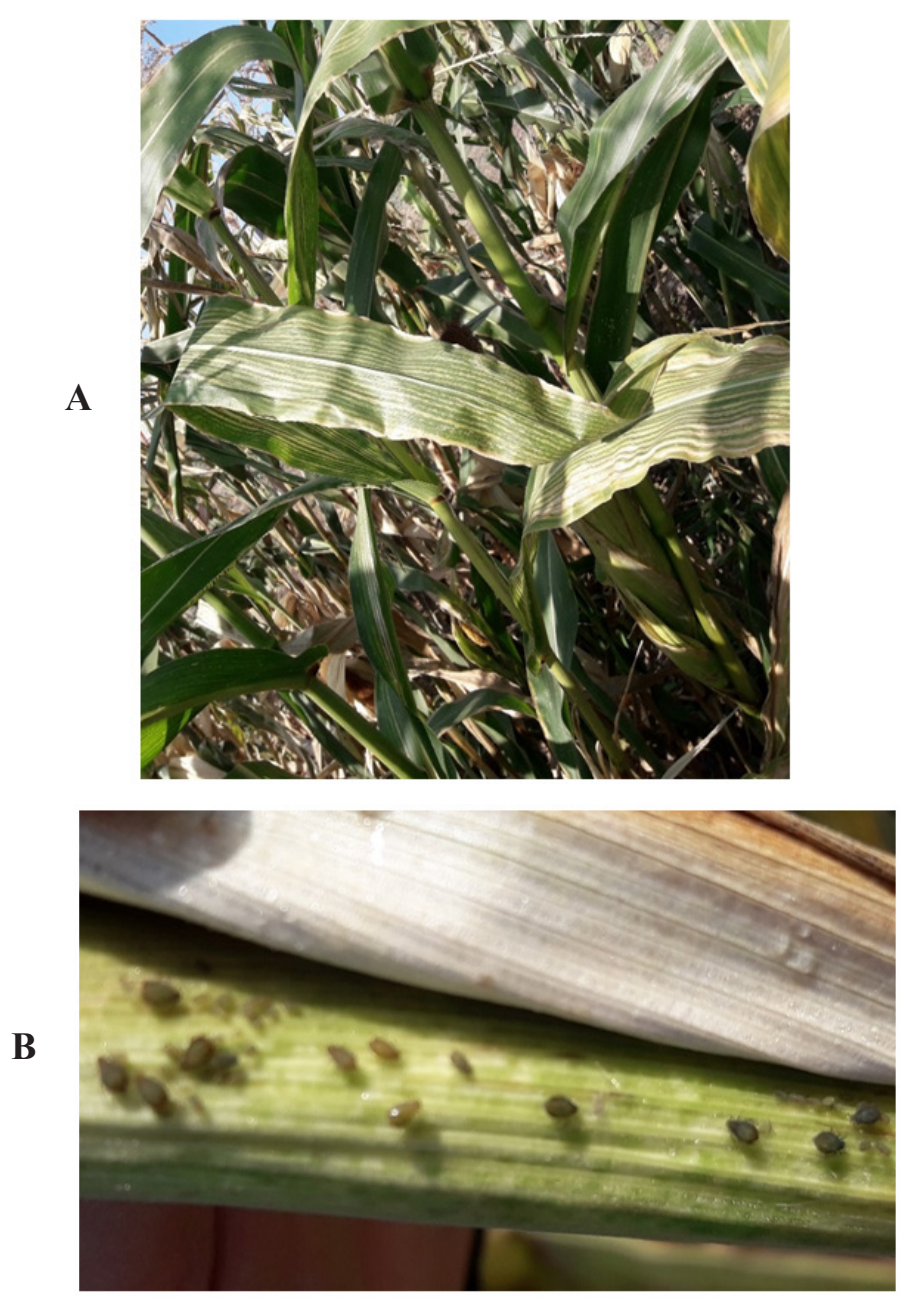

F i g. 5. Symptoms of mosaic (a) and aphids Rhopalosiphum padi (b) on maize plants in September 2020

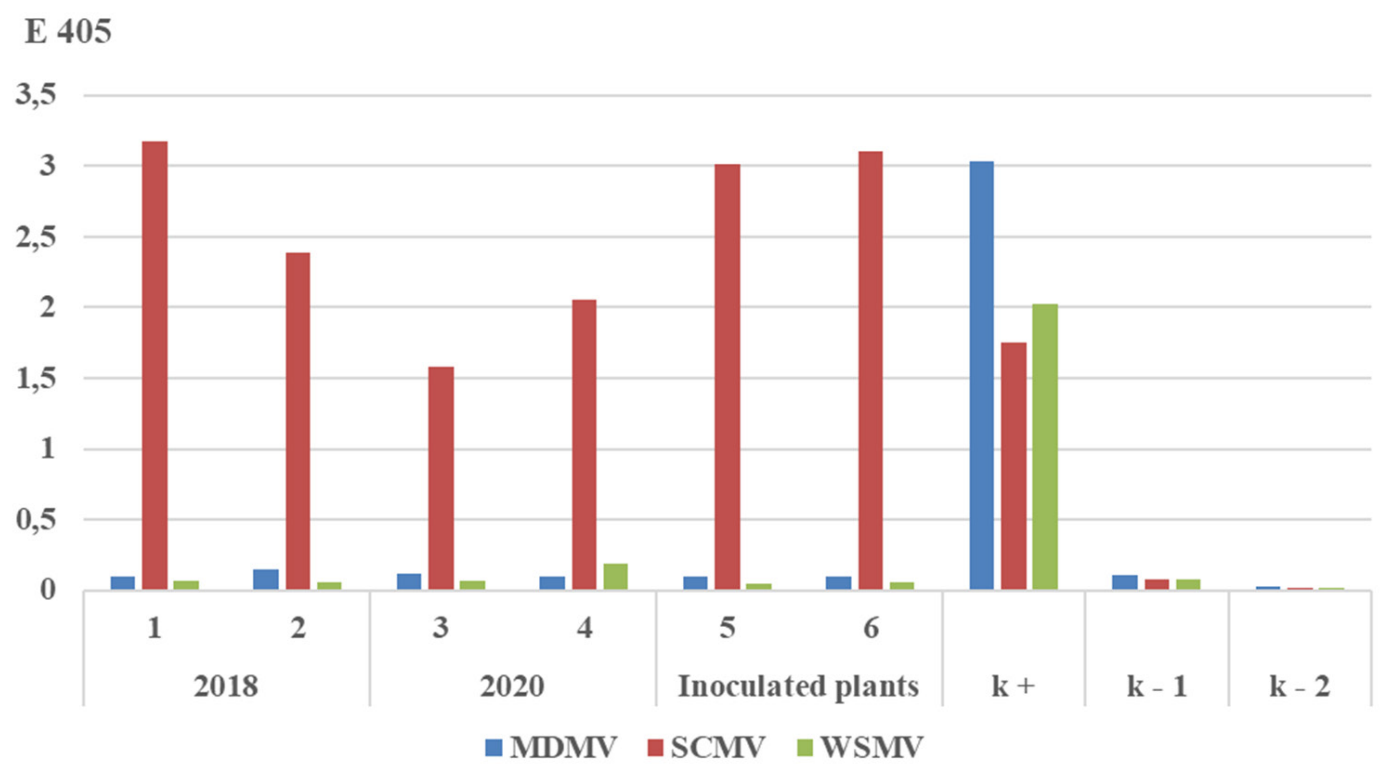

F i g. 6. DAS-ELISA detection of 3 (MDMV, SCMV, WSMV) viruses in maize plants with mosaic symptoms. Collected plant samples: 1 - mosaic (June 2018); 2 - mosaic and aphids

(August 2018); 3 - mosaic and aphids (September 2020); 4 - mosaic, aphids and growth retardation (September 2020). Maize plants of the "Mosquito" variety (5) and sweet maize plants of the "Brusnytsia" variety (6) inoculated with the sap of diseased plants. " $k$ +" - positive control; " $k-1$ " and " $k-2$ " - negative controls. 
previously healthy maize plants in August 2018, and the appearance of plants with mosaic and growth retardation symptoms and aphids in September 2020, as well as identification of the virus in these plants using DAS-ELISA suggests that Rhopalosiphum padi is a natural vector of SCMV in agrocenoses of Ukraine. Our observations are in accordance with the data of Hasan et al. (2003), they showed that R. padi and R. maidis had the highest viral transmission rates (92\%) among the tested aphid species [31]. Polyphagous $R$. padi is widely distributed in all regions of Ukraine. This is a major pest in cereals such as wheat and corn, and it is regarded to be a vector for several harmful plant viruses [47, 50-51].

Thus, the spread of SCMV in the agrocenoses of Ukraine most likely is due to a combination of two modes of transmission: by seed and by vector.

According to the literature reviewed, MDMV was detected on maize plants in Kyiv region of Ukraine in 1970-1971 based on plant host range, properties in the sap, particle morphology and transmission modes [40]. Analyzing these results after 50 years we cannot say with certainty which virus was circulating at that time, since it is impossible to distinguish MDMV and SCMV without serological and molecular methods.

Given that the scientific community recognizes the spread of MDMV in Ukraine, referring to the work of L.A. Naumenko [52-53], and taking into consideration the absence of data about distribution of SCMV we present the first report of SCMV in Ukraine.

Conclusions. This study presents the first record of Sugarcane mosaic virus in Ukraine in maize in Kyiv region. Sugarcane mosaic virus affected plants in monoinfection and its presence was confirmed by biotesting, electron microscopy and serological studies. Sugarcane mosaic virus circulates in the studied agrocenosis during 20182020 , and its spread is likely to occur through two modes of transmission: seed and Rhopalosiphum padi aphids.

\section{ПЕРШЕ ПОВІДОМЛЕННЯ \\ ПРО ВІРУС МОЗАЇКИ \\ ЦУКРОВОЇ ТРОСТИНИ \\ (SUGARCANE MOSAIC VIRUS) \\ НА КУКУРУДЗІ В УКРАЇНI}

\section{Г. Снігур ${ }^{1,2}$, А. Харіна ${ }^{1}$, М. Калюжна ${ }^{3}$, В. Чумак ${ }^{4}$ I. Будзанівська ${ }^{1}$}

${ }^{1}$ Київський національний університет імені Тараса Шевченка, ННЦ “Інститут біології та медицини”, кафедра вірусології, вул. Володимирська, 64/13, Киї, 01601, Украӥна ${ }^{2}$ Інститут мікробіологї і вірусології ім. Д.К. Заболотного НАН України, вул. Академіка Заболотного, 154, Київ, 03143, Украӥна

${ }^{3}$ Інститут зоології ім. I. I. Шмальгаузена НАН України, відділ систематики ентомофагів та екологічних основ біометоду, вул. Б. Хмельницького, 15 , Київ, 01030, Украӥна

${ }^{4}$ Держсвна установа вищсої освіти «Ужггородський національний університет»,

Кафедра ентомологї та збереження біорізноманіття, Народна площуа, 3, Ужсгород, 88000, Україна

Резюме

Вірусні хвороби кукурудзи у багатьох країнах завдають значних збитків, зокрема хвороба карликової мозаїки кукурудзи (Maize dwarf mosaic disease, MDMD), збудниками якої є потівіруси. Мета. Метою роботи було визначити збудника мозаїки кукурудзи, що спостерігалась на рослинах кукурудзи у 2018 та 2020 роках в Київській області. Методи. Для ідентифікації збудника хвороби кукурудзи у відібраних зразках використовували імуноферментний аналіз в модифікації DAS-ELISA із застосуванням комерційних тестсистем фірми Loewe Biochemica до вірусу карликової мозаїки кукурудзи (Maize dwarf mosaic virus, MDMV), вірусу мозаїки цукрової тростини (Sugarcane mosaic virus, SCMV) та вірусу смугастої мозаїки пшениці (Wheat streak mosaic virus, WSMV). Для прямого виявлення вірусних часток застосовували метод трансмісивної електронної мікроскопії. На хворих рослинах виявляли попелиць, які є природними векторами вірусів рослин. Результати. Рослини з типовими симптомами мозаїки виявили в посівах кукурудзи в Київській області на початку червня 2018 року. Збудник передавався механічною інокуляцією на рослини кукурудзи та десертної кукурудзи з про- 
явом симптомів мозаїки. У соці хворих рослин електронномікроскопічними дослідженнями було показано наявність гнучких нитчастих віріонів довжиною 750 нм та діаметром 13 нм, типових для представників роду Potyvirus. В серпні на раніше здорових рослинах в тих же посівах кукурудзи було виявлено симптоми мозаїки разом 3 попелицями Rhopalosiphum padi. У 2020 році на тій самій посівній площі кукурудза була без проявів вірусної інфекції при обстеженні у червні, а при повторному обстеженні у вересні було виявлено симптоми мозаїки на рослинах кукурудзи та присутність попелиць у пазухах листків. Присутність SCMV у зразках кукурудзи, відібраних у 2018 та 2020 роках як у червні, так і в серпні/вересні, а та-

1. Jiang JX, Zhou XP. Maize dwarf mosaic disease in different regions of China is caused by Sugarcane mosaic virus. Arch Virol. 2002; 147:24372443. doi: 10.1007/s00705-002-0890-7

2. Louie R, Knoke JK. Strains of maize dwarf mosaic virus. Plant Dis Reptr. 1975; 59:518-522.

3. Shukla DD, Frenkel MJ, McKern NM, Ward CW, Jilka J, Tosic M, Ford RE. Present status of sugarcane mosaic subgroup of potyviruses. Arch Virol (Suppl 5). 1992; 363-373.

4. Marie-Jeanne V, Ioos R, Peyre J, Alliot B, Signoret P. Differentiation of Poaceae Potyviruses by Reverse Transcription-Polymerase Chain Reaction and Restriction Analysis. J Phytopathology. 2000; 148(3):141-151.

5. Bagyalakshmi K, Parameswari B, Viswanathan R. Phylogenetic analysis and signature of recombination hotspots in sugarcane mosaic virus infecting sugarcane in India. Phytoparasitica. 2019; 47:275-291.

6. Cheng Y, Chen J, Chen J. The complete sequence of a sugarcane mosaic virus isolate causing maize dwarf mosaic disease in China. Sci. China C Life Sci. 2002; 45:322-330.

7. Gonçalves MC, Galdeano DM, Godoy ID, Martins C. Genetic variability of Sugarcane mosaic virus causing maize mosaic in Brazil. Pesqui Agropecuária Bras. 2011; 46:362-369.

8. Guadie D, Knierim D, Winter S, Tesfaye K, Abraham A. Survey for the identification and geographical distribution of viruses and virus diseases of maize (Zea mays L.) in Ethiopia. Eur кож в інокульованих рослинах кукурудзи і десертної кукурудзи була підтверджена за допомогою ELISA $з$ використанням комерційної тест-системи. Отримані дані дають можливість припустити, що Rhopalosiphum padi є природним вектором SCMV в агроценозах України. Слід зазначити, що сумісної інфекції з вірусом карликової мозаїки кукурудзи і вірусом смугастої мозаїки пшениці в уражених рослинах не виявлено. Висновки. У даному дослідженні представлено перше повідомлення про вірус мозаїки цукрової тростини (Sugarcane mosaic virus, SCMV) на кукурудзі в Україні.

Ключові слова: вірус мозаїки цукрової тростини, імуноферментний аналіз, кукурудза, Rhopalosiphum padi.

J Plant Pathol. 2019; 153:429-439. https://doi. org/10.1007/s10658-018-1568-7

9. He Z, Dong Z, Gan H. Genetic changes and host adaptability in sugarcane mosaic virus based on complete genome sequences. Mol Phylogenet Evol. 2020; 149: 106848. https://doi. org/10.1016/j.ympev.2020.106848

10. Moradi Z, Mehrvar M, Nazifi E, Zakiaghl M. The complete genome sequences of two naturally occurring recombinant isolates of Sugarcane mosaic virus from Iran. Virus Genes. 2016; 52(2):270-280. doi: 10.1007/s11262-016-13025.

11. Perera MF, Filippone MP, Ramallo CJ, Cuenya MI, García ML, Ploper LD, et al. Genetic diversity among viruses associated with sugarcane mosaic disease in Tucumán, Argentina. Phytopathology. 2009; 99:38-49.

12. Puchades Y, Lao M, Montalván J, Carvajal O, Martínez Y, Zardón MA, et al. Genetic and symptomatic characterization of Sugarcane mosaic virus (SCMV) in Cuba. Sugar Tech. 2016; 18: 184-191.

13. Shukla DD, Tosic M, Jilka J, Ford R, Toler R, Langham M. Taxonomy of potyviruses infecting maize, sorghum and sugarcane in Australia and the United States as determined by reactivities of polyclonal antibodies directed towards virus-specific N-termini of coat proteins. Phytopathology. 1989; 79:223-229.

14. Xie X, Chen W, Fu Q, Zhang P, An T, Cui A, et al. Molecular variability and distribution of 
Sugarcane mosaic virus in Shanxi. China. PLoS One. 2016; 11:e0151549.

15. Yahaya A, Dangora DB, Kumar PL, Alegbejo MD, Gregg L, Alabi OJ. Prevalence and genome characterization of field isolates of Sugarcane mosaic virus (SCMV) in Nigeria. Plant Dis. 2019; 103:818-824.

16. Tóbiás I, Bakardjieva N, Palkovics L. Comparison of Hungarian and Bulgarian Isolates of Maize Dwarf Mosaic Virus. Cereal Research Communications. 2007; 35(4):1643-1651. http:// www.jstor.org/stable/23789919

17. Silva KN, Nicolini C, Silva MS, Fernandes CD, Nagata T, Resende RO. First Report of Johnsongrass mosaic virus (JGMV) Infecting Pennisetum purpureum in Brazil. Plant Disease. 2013; 97(7):1003. 10.1094/PDIS-01-13-0013-PDN.

18. Stewart LR, Willie K, Wijeratne S, Redinbaugh MG, Massawe D, Niblett ChL, Kiggundu A, Asiimwe Th. Johnsongrass mosaic virus Contributes to Maize Lethal Necrosis in East Africa. Plant Dis. 2017; 101(8):1455-1462. doi: 10.1094/PDIS-01-17-0136-RE.

19. Mali VR, Thakur RP. Natural infection of sugarcane by an immunity breaking strain of sorghum mosaic potyvirus (SR MV-IBS) in peninsular India. Sugar Tech. 2000; 2:20-25. https://doi. org/10.1007/BF02945752

20. Zhang YL, Pennerman KK, Wang H, Yin G. Characterization of a Sorghum mosaic virus (SrMV) isolate in China. Saudi J Biol Sci. 2016; 23(2):237-242. doi: 10.1016/j.sjbs.2015.02.013

21. Gell G, Balázs E, Petrik K. Genetic diversity of Hungarian Maize dwarf mosaic virus isolates. Virus Genes. 2010; 40(2):277-281.

22. Mikel MA, D'Arcy CJ, Rhodes AM, Ford RE. Yield response of sweet maize to Maize dwarf mosaic virus. Plant Dis. 1981; 65:900-901. doi: 10.1094/PD-65-900.

23. Gates DW, Gudauskas RT. Photosynthesis, respiration and evidence of a metabolic inhibitor in maize infected with Maize dwarf mosaic virus. Phytopathology. 1969; 59:575-580.

24. Kannan M, Ismail I, Bunawan H. Maize Dwarf Mosaic Virus: From Genome to Disease Management. Viruses. 2018; 10(9):492. doi: 10.3390/ v10090492.
25. Luo Q, Ahmad K, Fu HY, Wang JD, Chen RK, Gao SJ. Genetic diversity and population structure of Sorghum mosaic virus infecting Saccharum spp. hybrids. Ann Appl Biol. 2016; 169:398407.

26. Achon MA, Serrano L, Alonso-Dueñas N, Porta C. Complete genome sequences of Maize dwarf mosaic and Sugarcane mosaic virus isolates coinfecting maize in Spain. Arch Virol. 2007; 152(11):2073-2078. doi: 10.1007/s00705007-1042-x

27. Marie-Jeanne V, Hariri D, Doucet R, Signoret PA. First Report of Sugarcane mosaic virus on Maize in the Centre Region of France. Plant Dis. 2011; 95(1):70. doi: 10.1094/PDIS-06-10-0426.

28. Pokorný R, Porubová M. The occurrence of viral pathogens of the genus Potyvirus on maize ( $\mathrm{Zea}$ mays L.) in the Czech Republic. Journal of Plant Diseases and Protection. 2000; 107(3):329-336.

29. Trzmiel K. First Report of Sugarcane mosaic virus Infecting Maize in Poland. Plant Disease. 2009; 93(10):1078. https://doi.org/10.1094/ PDIS-93-10-1078B

30. Thongmeearkom P, Ford RE, Jedlinski H. Aphid transmission of Maize dwarf mosaic virus strains. Phytopathology. 1976; 66:332-335. doi: 10.1094/Phyto-66-332.

31. Hasan M, Sahi GM, Wakil W, Imanat Y. Aphid transmission of sugarcane mosaic virus (SCMV). Pak J Agr Sci. 2003; 40(1-2):74-76.

32. Tu JC, Ford RE. Factors affecting aphid transmission of Maize dwarf mosaic virus to maize. Phytopathology. 1971; 61:1516-1521. doi: 10.1094/ Phyto-61-1516.

33. Berger P, Toler R, Harris K. Evidence for 2 modes of retention of Maize dwarf mosaic virus by Schizaphis graminum. Phytopathology. 1983; 73:787.

34. Wang RY, Pirone TP. Potyvirus transmission is not increased by pre-acquisition fasting of aphids reared on artificial diet. J Gen Virol. 1996; 77:3145-3148. doi: 10.1099/0022-1317-77-123145 .

35. Mikel MA, D’Arcy CJ, Ford RE. Seed Transmission of Maize dwarf mosaic virus in Sweet Maize. J Phytopathol. 1984; 110:185-191. doi: 10.1111/j.1439-0434.1984.tb00746.x. 
36. Boothroyd CW. Seed transmission of Maize dwarf mosaic virus in sweet maize and yield reduction in plants from an infected seed lot. Am Phytopathol Soc. 1977; 4:184. doi: 10.1111/ j.1439-0434.1984.tb00746.x.

37. Shepherd RJ, Holdeman QL. Seed transmission of the Johnsongrass strain of the Sugarcane mosaic virus in Maize. Plant Dis. 1965; 49:468-469.

38. Koike H. Sugar-cane Diseases: A Guide for Field Identification. 1988. 127p. Retrieved from http:// hdl.handle.net/10568/45118

39. Wangai AW, Redinbaugh MG, Kinyua ZM, Miano DW, Leley PK, Kasina M, Mahuku G, Scheets K, Jeffers D. First Report of Maize chlorotic mottle virus and Maize Lethal Necrosis in Kenya. Plant Disease. 2012; 96(10):1582. http:// dx.doi.org/10.1094/PDIS-06-12-0576-PDN

40. Naumenko LA. [Identification of maize mosaic virus]. Mikrobiolohichnyi Zhurnal. 1973; 35(4): 468-472. Ukrainian.

41. Naumenko LA. [Maize mosaic in Ukraine]. In: Bobyr AD, editor. Viruses and viral diseases of plants. Kyiv: Naukova Dumka. 1974. 203-206. Russian.

42. Browning IA. Bioassay for diagnosis of plant viruses. Methods Mol Biol. 2009; 508:1-13. doi: 10.1007/978-1-59745-062-1_1.

43. Richert-Pöggeler KR, Franzke K, Hipp K, Kleespies RG. Electron Microscopy Methods for Virus Diagnosis and High Resolution Analysis of Viruses Front. Microbiol. 2019; 9 (Article 3255):18. https://doi.org/10.3389/fmicb.2018.03255

44. Ward E, Foster SJ, Fraaije BA, Mccartney HA. Plant pathogen diagnostics: Immunological and nucleic acid-based approaches. Ann Appl Biol. 2004; 145:1-16.

45. Aphids on the World's Herbaceous Plants and Shrubs. 2006. Volume 2. The Aphids. By Blackman RL and Eastop VF. Published by John Wiley \& Sons Ltd, Chichester, in conjunction with The Natural History Museum, London, Hardcover, 1439 p.
46. Heie OE. The Aphidoidea (Hemiptera) of Fennoscandia and Denmark. III. Family Aphididae: subfamily Pterocommatinae and tribe Aphidini of subfamily Aphidinae. Fauna Entomol Scand. $1986 ; 17: 1-314$.

47. Mamontova VO. [Cereal aphids of Ukraine]. Kyiv: AN URSR, 1959. 94 p. Ukrainian.

48. Huth W, Lesemann D-E. Detection of maize dwarf mosaic and sugarcane mosaic viruses in the Federal Republic of Germany. In: Proceedings of the 5th Conference on Virus Diseases of Gramineae in Europe, 24-27 May 1988. Acta Phytopathol Entomol Hung. 1991; 26:125-130.

49. Awata L, Ifie BE, Tongoona P, Danquah E, Jumbo MB, Gowda M, Marchelo-D'ragga PW, Sitonik C, Suresh LM. Maize lethal necrosis and the molecular basis of variability in concentrations of the causal viruses in co-infected maize plant. Journal of general and molecular virology. 2019; 9(1):10.5897/JGMV2019.0073. https://doi. org/10.5897/JGMV2019.0073

50. Antipova LK, Shapovalov AI. [Harmful objects for winter wheat in the southern steppe of Ukraine under climate change]. In: Proceedings of the international scientific-practical conference "Strategy For Integration Of Agrarian Education, Science And Production: Global Challenges Of Food Security And Climate Change", 27-28 May, Mykolayiv, 2021. p. 70-72. Ukrainian.

51. FAO. 2021. Pests of economic importance in Ukraine. Integrated pest management manual. Budapest, Hungary. 190 p. https://doi. org/10.4060/cb3909en

52. Electronic resource: https://www.cabi.org/isc/ datasheet/8157\#toDistributionMaps

53. Electronic resource: http://www.agroatlas.ru/en/ content/diseases/Zeae/Zeae_Maize_dwarf_mosaic_potyvirus/index.html

Received 3.07.2021 